\title{
PReS-FINAL-2213: Validation of inadequate drug response and definition of colchicum resistance in FMF
}

\author{
E Demirkaya*, C Acikel, G Basbozkurt, A Gul, O Kasapcopur, O Aydog, H Erdem, A Duzova, B Kisacik, T Kasifoglu, \\ E Erken, M Tunca, M Sayarlioglu, S Yuksel, F Yildiz, O Donmez, A Berdeli, S Senel, NA Ayaz, A Polat, B Sozer, \\ Y Tabel, S Akar, AM Onat, O Ozkaya, S Emre, N Akinca, G Ozcelik, S Yavuz, S Yesilkaya, F Gok, HM Poyrazoglu, \\ H Direskeneli, S Bakkaloglu, S Erten, A Tufan, B Goker, S Kavukcu, N Cakar, M Saldir, A Delibas, B Makay, \\ A Kısaarslan, SE Unsal, H Ozdogan, R Topaloglu, S Ozen
}

From 20th Pediatric Rheumatology European Society (PReS) Congress

Ljubljana, Slovenia. 25-29 September 2013

\section{Introduction}

Colchicine is effective in controlling the attacks and preventing the development of amyloidosis. Moreover many new generation drugs may be used in FMF treatment. About $5-10 \%$ of the patients do not respond to colchicine and inadequate response to other drugs is not as clear as the unresponsiveness of colchicine.

\section{Objectives}

In this study it was aimed to determine the set of criteria for the diagnosis of inadequate drug response in FMF.

\section{Methods}

This study was based on a Delphi survey. Open-ended questions were sent to 70 experts on FMF. In the first Delphi round, clinical and laboratory findings indicating colchicine resistance and the protocol, which would define resistance to treatment and exclusion criteria, were asked. Based on the results of the first Delphi, a second Delphi form, which included 5 evaluation questions, was developed. In this latter form the questions to be used in order to define complete response, partial response and non-response were tried to be determined. As a last step, a consensus meeting held on by attendance of 12 (6 of pediatric rheumatologist and 6 of adult rheumatologist) experts. The experts evaluated all

\footnotetext{
FMF Arthritis Vasculitis and Orphan disease Research in Pediatric
} Rheumatology (FAVOR), Ankara, Turkey

\section{Conclusion}

Assessing the colchicine resistance via concrete and agreed scale will provide a reliable data. The criteria set considerate as valid for evaluation of inadequate drug response. There is no statistically difference between 6 items and 7 items criteria sets. On the other hand recovery of 
arthritis maybe more valuable among adult patients. A prospective validation study will be conducted with daily outpatient cases.

\section{Disclosure of interest}

None declared.

Published: 5 December 2013

doi:10.1186/1546-0096-11-S2-P203

Cite this article as: Demirkaya et al:: PReS-FINAL-2213: Validation of inadequate drug response and definition of colchicum resistance in FMF. Pediatric Rheumatology 2013 11(Suppl 2):P203.

Submit your next manuscript to BioMed Central and take full advantage of:

- Convenient online submission

- Thorough peer review

- No space constraints or color figure charges

- Immediate publication on acceptance

- Inclusion in PubMed, CAS, Scopus and Google Scholar

- Research which is freely available for redistribution

Submit your manuscript at www.biomedcentral.com/submit 